Jurnal Perpustakaan Universitas Airlangga:

Media Informasi dan Komunikasi Kepustakawanan

https://e-journal.unair.ac.id/JPERPUS

\section{MANAGEMENT OF PERSONAL INFORMATION BY SMAN 1 CICALENGKA STUDENTS IN OVERCOMING LEARNING OBSTACLES DURING THE COVID-19 PANDEMIC}

\section{MANAJEMEN INFORMASI PRIBADI OLEH SISWA SMAN 1 CICALENGKA DALAM MENGATASI KENDALA BELAJAR SAAT PANDEMI COVID-19}

\author{
Mindy Syailah Nurthoyyibah*, Laksmi Dewi, Dian Arya Susanti \\ Universitas Pendidikan Indonesia, Bandung- Indonesia
}

\section{Research Report \\ Penelitian}

\section{INFO ARTICLE}

Received: June 2021

Accepted: October 2021

Published: Nopember 2021

Korespondensi:

Mindy Syailah Nurthoyyibah

Email:

syailahmindy@upi.edu

\section{Keywords:}

Personal Information Management, High School

Students, Learning

Constraints, Covid-19

Pandemic.

Jurnal Perpustakaan Universitas Airlangga: Media Informasi dan Komunikasi Kepustakawanan p-ISSN: 2356-1408; e-ISSN: 2723-0554

Open access under Creative Commons Attribution-Non Commercial-Share A like 4.0 International Licence

(CC-BY-NC-SA) 


\section{A B S T R A K}

Pandemi Covid-19 memberikan tantangan kepada seluruh pihak dalam berbagai aktivitas manusia khususnya pendidikan. Pelaksanaan pembelajaran jarak jauh menjadi salah satu solusi yang tepat untuk kegiatan belajar mengajar saat ini. Informasi yang terus bertambah dapat menjadi bantuan atau bahkan kerugian karena penumpukan informasi. Hadirnya pembelajaran jarak jauh dan berkembangnya informasi yang begitu cepat pada saat ini memberikan dampak pada siswa, salah satunya kendala belajar. Kendala belajar memiliki dampak negatif terhadap perkembangan kompetensi dan pengetahuan siswa. Penelitian ini menggunakan metode kuantitatif deskriptif dengan analisis rating scale meliputi perhitungan nilai indeks minimum, nilai indeks maksimum, interval, jarak interval dan presentase skor, serta analisis data yang dibantu IBM SPSS Statistics 25. Manajemen informasi pribadi dapat menjadi salah satu solusi untuk menanggulangi masalah yang sedang dihadapi penggunanya. Hasil penelitian mengungkapkan bahwa aktivitas manajemen informasi pribadi siswa tergolong baik, akan tetapi perlu adanya peningkatan dan perhatian lebih khususnya tahap penyimpanan, pengorganisasian, dan pemeliharaan untuk kesuksesan proses temu balik informasi. Manajemen informasi pribadi juga memiliki hubungan dan pengaruh positif terhadap kendala belajar siswa saat pandemi Covid-19.

\section{PENDAHULUAN}

Hadirnya pandemi Covid-19 memberikan dampak yang kuat terhadap aktivitas manusia di seluruh dunia, termasuk Indonesia. Beberapa dampak baik dalam bidang ekonomi, sosial, budaya, agama maupun pendidikan dapat dirasakan ketika pemerintah mulai menetapkan pembatasan aktivitas yang menyebabkan kerumunan. Beberapa kebijakan tersebut seperti Pembatasan Sosial Berskala Besar (PSBB), Pemberlakuan Pembatasan Kegiatan Masyarakat (PPKM), Pembelajaran Jarak Jauh (PJJ), dan lainlain.

Penyelenggaraan Pembelajaran Jarak Jauh (PJJ) menjadi salah satu solusi atas masalah pendidikan yang diterapkan di tengah pandemi Covid-19. Kebijakan tersebut diharapkan mampu mengatasi ketimpangan pendidikan yang didapatkan oleh masyarakat Indonesia yang semakin membesar. Namun, dalam pelaksanaannya Pembelajaran Jarak Jauh (PJJ) memiliki kendala tersendiri baik itu untuk peserta didik, pendidik maupun orang tua. Hasil penelitian Dutta \& Smita (2020) mengungkapkan bahwa sebagian besar siswa dan mahasiswa di negara Bangladesh menghadapi gangguan belajar, sulitnya menjalin komunikasi, serta kesehatan fisik dan mental yang menurun. Kemudian didukung dari hasil penelitian Rinawati \& Darisman (2020) bahwa siswa SMK mengalami kendala belajar berupa kejenuhan

\section{Kata Kunci:}

Manajemen Informasi

Pribadi, Siswa SMA, Kendala

Belajar, Pandemi Covid-19. dalam proses Pembelajaran Jarak Jauh (PJJ) seperti kelelahan secara fisik, sosial maupun mental, penurunan prestasi dan depersonalisasi.

Kendala belajar dihadapi oleh siswa bersamaan dengan perkembangan informasi yang terus meluas. Akses informasi memberikan kemudahan kepada setiap penggunanya dalam menjalankan peran yang diemban. Khususnya pada siswa sebagai komponen pendidikan dalam mendukung terciptanya pendidikan yang efektif dan produktif. Namun, kemudahan dalam mendapatkan informasi juga memberikan peluang besar dalam mendapatkan informasi yang salah serta keberlimpahan informasi (information overload). Keberlimpahan informasi tersebut memberikan dampak seperti kelelahan bahkan meningkatkan stres penggunanya.

Manajemen informasi pribadi ataupun Personal Information Management (PIM), dapat dijadikan sebagai upaya dalam menanggulangi masalah tersebut. Sesuai dengan pernyataan livari et al. (2020) mengungkapkan bahwa terjadi kesenjangan akibat dari pandemi Covid-19 pada perubahan teknologi khususnya dalam ruang lingkup pendidikan. Sehingga sekolah perlu memperhatikan lebih lanjut terkait implementasi pengelolaan informasi untuk pendidik maupun peserta didik dalam menunjang pelaksanaan tugas dan kewajibannya. Shafira (2020) menyatakan bahwa implementasi manajemen informasi pribadi menjadi salah satu kompetensi 
yang diperlukan untuk melakukan pengelolaan atas informasi yang dimiliki sehingga dapat menunjang karir maupun meningkatkan kompetensi digital abad ke-21. Kemudian Zhang (2016) mengungkapkan dalam penelitiannya bahwa manajemen informasi pribadi melalui ponsel memiliki pengaruh terhadap efektivitas belajar mahasiswa di perguruan tinggi.

Berdasarkan latar belakang di atas dapat disimpulkan bahwa manajemen informasi pribadi dapat membantu penggunanya untuk memanfaatkan informasi dengan baik secara efektif dan efisien. Tanpa pengelolaan informasi akan terjadinya penumpukan. Penumpukan informasi tersebut akan memberikan kesulitan yang berkelanjutan bagi penggunanya dalam mengakses informasi untuk mengatasi masalah yang sedang dihadapi. Selain itu dengan kendala belajar yang dihadapi oleh sebagian besar siswa saat pandemi Covid-19 di Indonesia khususnya SMAN 1 Cicalengka, peneliti berharap manajemen informasi pribadi ini dapat menjadi salah satu solusi atas masalah yang sedang dihadapi.

\section{TINJAUAN PUSTAKA}

\section{- Manajemen Informasi}

Manajemen merupakan suatu sistem yang bekerjasama dengan bantuan sumber dayasumber daya dan sebagai fasilitasnya secara efektif dan efisien untuk mencapai tujuan yang diinginkan (Suhardini, 2011: 15). Sedangkan informasi menurut Darmawan (2012) adalah kumpulan data berupa angka, ungkapan, gambar, tanda, bentuk ataupun simbol lainnya yang melalui proses pengolahan dan interpretasi data.

Manajemen informasi merupakan serangkaian aktivitas yang berkaitan dengan data dan fakta sebagai informasi bagi penggunanya. Pernyataan tersebut didukung oleh Karim \& Hussein (2008) yang mengungkapkan bahwa manajemen informasi sebagai serangkaian aktivitas yang memberikan dorongan kepada penggunanya dalam memanfaatkan informasi serta data yang dimiliki secara maksimal. Sedangkan menurut Thomson (n.d.) bahwa manajemen informasi tidak hanya berbicara tentang informasi dan pengelolaannya, tertapi juga berkaitan dengan retensi masa aktif, kontrol kualitas dan aksesibilitasnya. Tujuan dari implementasi manajemen informasi adalah "is to harness the information resources and information capabilities of the organization in order to enable the organization to learn and adapt to its changing environment" (Choo, 1995; Auster \& Choo, 1995; Choo, 2002: 5).

\section{- Manajemen Informasi Pribadi}

Informasi pribadi berkaitan dengan suatu individu baik itu ditemukan, disimpan, dikelola dan digunakan oleh individu tersebut. Majid et al. (2010) memaparkan terkait manajemen informasi pribadi sebagai serangkaian kegiatan yang meliputi menemukan, membuat, menyimpan, mengelola, memelihara, menggunakan dan mendistribusikan informasi pribadi sebagai upaya dalam memandu pelaksanaan tugas atas tanggung jawab yang diemban. Kemudian manajemen informasi pribadi merupakan aktivitas yang melibatkan metode dan prosedur untuk menyimpan, mengelola, mengambil dan menampilkan informasi pribadi dalam files, emails, bookmarks maupun multimedia (Al Nasar et al., 2011: 197). Berikut beberapa rangkaian aktivitas manajemen informasi yang disampaikan oleh William Jones \& Teevan, (2008) dan Whittaker (2011):

\section{a. William Jones \& Teevan (2008)}

Rangkaian aktivitas yang diungkapkan oleh William Jones \& Teevan (2008) merupakan pengembangan atas teori Barreau. Berikut rincian aktivitas pengelolaan informasi pribadi:

\section{Finding and refinding information}

Aktivitas penemuan informasi atas keingintahuan, kebutuhan atau permasalahan yang sedang dihadapi. Kemudian melakukan penemuan kembali informasi sebagai upaya penyempurnaan informasi yang dimiliki.

2. Keeping and organizing information

Setelah ditemukan, informasi akan melalui tahap penyimpanan atas informasi yang diperlukan untuk saat ini maupun masa yang akan datang. Selanjutnya melalui tahap pengelolaan informasi berdasarkan tanggal, isi, judul, nama penulis maupun format isi untuk mempermudah proses temu kembali informasi. Pada tahapan ini pengguna juga dapat memerhatikan lebih lanjut kegiatan 
penamaan, pelabelan, pengelompokan dan pengklasifikasian (Wahyuni, 2019: 13).

3. Meta-level information

Aktivitas lanjutan dari teori ini adalah informasi tingkatan meta atau meta-level information yang meliputi kegiatan mengelola, memelihara, mempertahankan dan mengatur informasi yang dimiliki.

b. Whittaker (2011)

Aktivitas pengelolaan informasi pribadi ini Whittaker (2011) menyebutnya dengan information curation atau kurasi informasi. Karena setiap orang yang memutuskan untuk melakukan penyimpanan dan pemeliharaan informasi akan berkaitan dengan proses kurasi dan preservasi informasi yang tidak hanya dimiliki oleh suatu organisasi tetapi juga setiap individu. Berikut rangkaian aktivitas kurasi informasi dari Whittaker (2011)

\section{Keeping}

Whittaker (2011) mengungkapkan bahwa pada aktivitas penyimpanan informasi ini sebagian besar individu memiliki keraguan yang tinggi untuk menyimpan informasi yang ditemukannya. Hal ini berhubungan dengan kemampuan memprediksi dan menganalisis kebutuhan di masa yang akan datang.

2. Management

Tahap kedua pada teori ini adalah pengelolaan informasi. Aktivitas pada tahapan ini berupa penambahan nama, pelabelan, pembersihan, pemeliharaan dan mempertahankan informasi dengan memprediksi dan menganalisis kebutuhan di masa depan.

3. Exploitation

Exploitation atau lebih tepatnya dengan pemanfaatan informasi yang telah dikelola sesuai dengan kebutuhan penggunanya. Dalam memanfaatkan informasi ini pengguna dapat menggunakan empat cara yaitu: Navigation (pencarian manual melalui folder sub-folder), Search (pencarian melalui kata kunci), Orienteering (pencarian yang menggabungkan search dan navigation), dan Tangging (pencarian menggunakan tanda atau label ketika informasi di simpan).

Kedua teori antara William Jones \& Teevan (2008) dan Whittaker (2011) memiliki kesamaan dalam proses implementasi manajemen informasi pribadi yaitu meliputi penyimpanan, pengelolaan dan pemeliharaan informasi yang dimiliki. Perbedaannya terletak pada aktivitas pertama teori William Jones \& Teevan (2008) yaitu finding and refinding information dan teori Whittaker (2011) pada tahap exploitation. Berikut hasil komparasi aktivitas manajemen informasi pribadi dan siklus hidup kurasi informasi oleh Whittaker (2011) yang akan digunakan pada penelitian ini:

Tabel 1. Komparasi Aktivitas PIM dan Siklus Hidup Kurasi Informasi

\begin{tabular}{|c|c|}
\hline $\begin{array}{c}\text { Personal Information Management Activities by } \\
\text { William and Teevan (2008) }\end{array}$ & $\begin{array}{c}\text { Curation Lifecycle by } \\
\text { Whittaker (2011) }\end{array}$ \\
\hline Finding and Refinding & Keeping \\
\hline Keeping & Management \\
\hline Mera-level activities & Exploitation \\
\hline
\end{tabular}

Sumber: Whittaker (2011) 


\section{- Kendala Belajar Saat Pandemi Covid-19}

Centers for Disease Control and Prevention mengutarakan pandemi berasal dari epidemi yang menyebar ke beberapa negara atau benua (National Center for Health Statistics, 2005; Handayani et al., 2020: 374). Hadirnya pandemi memberikan dampak serius terhadap siklus hidup manusia seperti yang diungkapkan oleh United Nations Development \& Programme (2020) bahwa, dampak pandemi tidak hanya berkaitan dengan sosial dan ekonomi saja. Juga berpengaruh secara signifikan terhadap budaya, pekerjaan, keamanan, kenyamanan, hiburan bahkan pendidikan yang memiliki dampak paling panjang di masa yang akan datang.

Belajar sebagai salah satu proses memanusiakan manusia, mendewasakan manusia, dan meningkatkan kompetensi manusia saat ini sebagian besar dilaksanakan secara berjejaring. Wiresti (2020) mengungkapkan bahwa pembelajaran secara tatap maya menjadi salah satu solusi terbaik dalam upaya mengembangkan potensi dan kompetensi siswa. Namun pelaksanaan pembelajaran tersebut memiliki tantangan yang besar salah satunya seringkali disebut sebagai kendala belajar. Kemudian, definisi kendala belajar yang diungkapkan oleh Lestari (2016) sebagai segala sesuatu yang memberikan dampak terhadap menurunnya dorongan untuk belajar baik secara internal maupun eksternal. Kemudian Neuwirth et al. (2020: 7-8) dalam penelitiannya memaparkan beberapa kendala belajar saat pandemi Covid-19 ketika pembelajaran tatap maya, seperti: kesulitan untuk fokus ketika pembelajaran sedang berlangsung, kurangnya dorongan semangat peserta didik untuk berpartisipasi ketika diskusi, dan rasa jenuh akan aktivitas yang sama dalam waktu yang lama.

\section{METODE PENELITIAN}

Penelitian ini menggunakan pendekatan kuantitatif sebagai "salah satu jenis penelitian yang spesifikasinya adalah sistematis, terencana, dan terukur dengan jelas sejak awal hingga pembuatan desain penelitiannya" (Siyoto \& Sodik, 2015: 17). Kemudian peneliti juga menggunakan metode statistika deskriptif untuk mendapatkan hasil analisa yang lebih detail dari data yang didapatkan.

Populasi yang terlibat dalam penelitian ini adalah seluruh siswa SMAN 1 Cicalengka dengan jumlah sampel sebanyak 89 siswa kelas $X$ (sepuluh) dan XI (sebelas) berdasarkan hasil perhitungan menggunakan rumus slovin (dalam Riyanto \& Hatmawan, 2020) berikut:

$$
n=\frac{N}{1+N e^{2}}
$$

\section{Keterangan: \\ $\mathrm{n}$ : Jumlah Sampel \\ $\mathrm{N}$ : Jumlah Total Populasi \\ e : Tingkat Kesalahan}

Untuk teknik pengumpulan data yang digunakan yaitu kuesioner dengan skala likert dan menghilangkan jawaban netral serta penggunaan data sekunder berupa informasi yang sekiranya diperlukan untuk melengkapi hasil analisis data. Instrumen pada penelitian ini memanfaatkan hasil komparasi aktivitas manajemen informasi pribadi William Jones \& Teevan (2008) dan Whittaker (2011) sebagai variabel bebas dan kendala belajar saat pandemi Covid-19 sebagai variabel terikat dengan jumlah seluruhnya 23 item. Sedangkan untuk analisis data peneliti menggunakan perhitungan presentasi pada skor yang diperoleh, menggunakan rating scale dengan menemukan nilai indeks minimum; nilai indeks maksimum; interval; jarak interval dan presentase skor, serta dibantu dengan aplikasi IBM SPSS Statistics 25 untuk mengetahui normalitas, linearitas dan pengaruh antar variabel pada data responden yang terkumpul.

\section{HASIL DAN PEMBAHASAN}

Hasil dari pengumpulan data pada kuesioner yang disebarkan kepada seluruh siswa SMAN 1 Cicalengka menunjukkan bahwa sebagian besar siswa yang berpatisipasi adalah perempuan dibandingkan laki-laki. Kemudian sebanyak 6\% berusia 18 tahun, 35\% berusia 17 tahun dan sebagian besar lainnya dengan jumlah presentase $58 \%$ berusia 16 tahun. Seluruh 
responden terdiri dari $51 \%$ kelas $X$ (sepuluh) dan 49\% kelas XI (sebelas), dikarenakan siswa kelas XII sudah menempuh kelulusannya sebagai siswa SMAN 1 Cicalengka pada tahun 2021 ini.

Perkembangan informasi yang terus bertambah memberikan dua sisi mata pisau terhadap penggunanya. Satu sisi informasi yang ditemukan dan disimpan menjadi bantuan besar, sisi lainnya akan menjadi masalah yang berkepanjangan karena terjadinya penumpukan informasi. Penumpukan informasi pada media penyimpanan seperti ponsel, laptop ataupun komputer merupakan salah satu dampak dari tidak adanya pengelolaan informasi.

Pengelolaan informasi dapat dilakukan oleh siapapun termasuk siswa yang memiliki peran sebagai peserta didik dalam ruang lingkup pendidikan. Pernyataan tersebut sesuai dengan ungkapan dari Hardof-Jaffe et al. (2009) bahwa setiap peserta didik memerlukan pengetahuan yang membantunya dalam melakukan pengelolaan atas informasi pribadi untuk mendukung setiap peran yang dimilikinya dimanapun mereka berada. Informasi pribadi merupakan informasi yang ditemukan, disimpan dan dikelola untuk diri sendiri (Jones, 2007).

\section{- Aktivitas Manajemen Informasi Pribadi}

Berikut aktivitas pengelolaan informasi pribadi siswa SMAN 1 Cicalengka berdasarkan hasil analisis pada data yang terkumpul:

1. Penemuan Informasi

Pencarian informasi merupakan tahap awal pada proses pengelolaan atas informasi pribadi siswa berdasarkan pemaparan dari teori William Jones \& Teevan (2008). Penemuan informasi terjadi karena ada dorongan dalam diri siswa sebagai upaya penyelesaian masalah yang sedang dihadapi, khususnya pada masa pandemi Covid-19 dengan sistem pembelajaran yang mengedepankan tatap maya.

Pandemi Covid-19 juga memberikan dorongan yang besar terhadap siswa untuk bersikap mandiri selama Pembelajaran Jarak Jauh (PJJ) berlangsung. Berdasarkan hasil analisis data sebanyak $17 \%$ siswa memerlukan waktu kurang dari 5 menit untuk melakukan pencarian informasi. Sebanyak $15 \%$ siswa memerlukan waktu lebih dari 10 menit dan sebanyak 68\% siswa memerlukan 5-10 menit untuk menemukan informasi yang sesuai dengan kebutuhannya.

Eksistensi ponsel yang dijadikan sebagai media pada proses pencarian informasi oleh siswa SMAN 1 Cicalengka ini lebih tinggi dibandingkan laptop dan komputer. Kemudian, sebagian besar siswa juga menerima dan membagikan informasi melalui sosial media seperti whatsapp, instagram, telegram, dan lain-lain. Sedikit siswa yang akrab dengan e-mail, clouds, google drive, dropbox, dan lain-lain. serta penggunaan flashdisk atau $\mathrm{CD}$ yang beriringan dengan terbatasnya pertemuan secara tatap muka.

Pencarian informasi siswa berkaitan dengan materi pembelajaran, pengembangan diri, motivasi, hobi ataupun hiburan yang menunjang terlaksananya tanggung jawab setiap individu. Sesuai dengan pernyataan Detlor (2010: 103) bahwa informasi pribadi berkaitan dengan informasi yang memberikan bantuan terhadap penggunanya pada kegiatan sehari-hari. Kemudian ketika pencarian informasi, siswa SMAN 1 Cicalengka sudah memahami apa, bagaimana, serta keberadaan informasi yang diperlukan. Siswa SMAN 1 Cicalengka juga sebagian besar melakukan pencarian informasi pada situs terpercaya secara berjejaring seperti academia.edu, brainly, ruang guru dan situs sejenis lainnya. Sayangnya, aktivitas pencarian kembali informasi sebagai upaya dalam menyempurnakan informasi yang diperlukan masih perlu ditingkatkan lagi.

2. Penyimpanan Informasi

Penyimpanan merupakan tahapan lanjutan dari rangkaian aktivitas manajemen informasi pribadi. Whittaker (2011) mengungkapkan bahwa aktivitas penyimpanan informasi memerlukan ketelitian dan usaha lebih. Sejalan dengan pemaparan tersebut Jones (2017; Lush, 
2014) mengatakan bahwa seseorang akan mengalami keraguan dalam dirinya setelah menemukan informasi yang tepat. Kedua pernyataan tersebut terbukti pada hasil penelitian bahwa sebagian besar siswa SMAN 1 Cicalengka ragu ketika dihadapkan pada aktivitas penyimpanan informasi. Keraguan tersebut dapat membaik beriringan dengan upaya meningkatkan aktivitas analisis informasi yang diperlukan di masa yang akan datang.

Aktivitas penyimpanan informasi siswa tergolong baik dengan presentase $75 \%$. Siswa dapat menyimpan informasi berdasarkan tanggal dan isi, namun aktivitas tersebut belum dapat dilaksanakan secara konsisten sehingga memberikan kendala terhadap pelaksanaan temu balik.

Dalam proses penyimpanan informasi tentu akan berkaitan dengan media yang digunakan (Wahyuni, 2019). Meskipun berhadapan dengan pandemi Covid-19 serta pertumbuhan teknologi yang cepat, siswa lebih akrab dengan penyimpanan informasi pada kapasitas memori ponsel - meskipun beberapa diantaranya juga memanfaatkan kapasitas memori laptop dan komputer, dibandingkan dengan penyimpanan secara berjejaring seperti penggunaan google drive, clouds, e-mail, dropbox, dan lain-lain.

3. Pengorganisasian Informasi

Proses penyimpanan informasi juga berkaitan erat dengan proses pengorganisasian informasi. Wahyuni (2019: 13) mengungkapkan bahwa rincian aktivitas pada proses ini yaitu: a) Pemberian nama, b) Pemberian tanda, dan c) Pengelompokan informasi. Kemudian didukung oleh pemaparan Indratmo \& Vassileva (2008: 4) bahwa pemberian tanda menjadi salah satu bagian terpenting yang menghubungkan informasi satu dengan informasi lainnya sehingga mudah dalam melakukan temu balik informasi.

Berdasarkan hasil analisis data bahwa aktivitas pengroganisasian siswa SMAN 1 Cicalengka tergolong baik dengan presentase sebesar 75\%. Akan tetapi aktivitas ini perlu ditingkatkan lagi khususnya dalam konsistensi penyimpanan dan pengorganisasian informasi sesuai dengan aktivitas sebelumnya, sehingga memudahkan siswa dalam melakukan proses temu balik di masa yang akan datang.

4. Pemeliharaan Informasi

Aktivitas lanjutan yaitu pemeliharaan informasi. Pada William Jones \& Teevan (2008) aktivitas pemeliharaan ini terletak pada tahapan meta-level information, sedangkan pada teori Whittaker (2011) terletak pada tahapan managing information. William Jones \& Teevan (2008) mengungkapkan bahwa pada tahapan ini perlu memahami lebih lanjut terkait aktivitas pemeliharaan informasi, mengatur masuk dan keluarnya informasi, evaluasi dan penggunaan informasi yang memiliki tantangan lebih tinggi dibandingkan dengan aktivitas lainnya. Hasil penelitian menunjukkan bahwa siswa mampu melaksanakan pemeliharaan informasi dengan sangat baik melalui presentase angka $81 \%$.

Pada tahapan ini siswa memperhatikan kebaruan informasi, penghapusan informasi termasuk mempertimbangkan aktivitas alih media ke dalam format lainnya. Siswa melakukan pengarsipan sebagai upaya dalam menjaga informasi dari kerusakan dan kehilangan. Lalu, melakukan seleksi atas informasi yang dimiliki dalam upaya mempermudah proses temu balik dan menjaga kapasitas memori media yang digunakan. Akan tetapi masih terdapat aktivitas yang perlu ditingkatkan lagi yaitu konsistensi pemeliharaan informasi. Sesuai dengan pernyataan Marchand, et al. (2001; Hwang et al., 2015) bahwa pemeliharaan informasi ini memiliki dampak dalam proses pemanfaatan informasi sesuai dengan kebutuhannya di masa yang akan datang.

\section{Pemanfaatan Informasi}

Selanjutnya adalah aktivitas pemanfaatan informasi pribadi yang diungkapkan oleh Whittaker (2011) pada "Siklus Hidup Kurasi Informasi". Aktivitas ini bukanlah aktivitas terakhir, karena seluruh rangkaian pengelolaan informasi pribadi ini akan terus 
berulang selama siswa masih menggunakan dan memerlukan informasi dalam mengatasi berbagai masalah yang sedang dihadapi.

Hasil penelitian menunjukan bahwa aktivitas pemanfaatan informasi tergolong baik dengan presentase sebesar $73 \%$. Pernyataan tersebut terbukti bahwa siswa mampu melakukan pencarian informasi berdasarkan folder sub-folder, kata kunci ataupun memanfaatkan tanda yang telah dibuat.

Ternyata sebagian besar siswa SMAN 1 Cicalengka masih perlu meningkatkan aktivitas penyimpanan, pengorganisasian dan pemeliharaan informasi. Kemudian melatih diri untuk meningkatkan kemampuan dalam menemukan informasi secara cepat berdasarkan folder dan sub foldernya, kata kunci maupun tanda. Pernyataan tersebut sesuai dengan kondisi sebagian siswa yang memiliki kesulitan dalam proses temu balik informasi. Jika kesulitan tersebut terus berlanjut, tentu hal ini akan bertentangan dengan pernyataan Robinson \& Johnson (2012) yaitu tujuan dari adanya personal information management di lingkungan siswa
- Manajemen Informasi Pribadi Dalam Mengatasi Kendala Belajar Siswa Saat Pandemi Covid-19

Kendala belajar dihadapi oleh sebagian besar siswa SMAN 1 Cicalengka selama pandemi Covid-19. Pernyataan tersebut terbukti dari hasil presentase sebesar $81 \%$. Kendala tersebut muncul dipengaruhi oleh keadaan internal maupun eksternal (Lestari, 2016). Jika terus berlanjut maka akan menyebabkan penurunan kinerja otak termasuk kompetensi siswa beberapa saat yang akan datang.

Sebagian besar siswa menyetujui ungkapan bahwa Pembelajaran Jarak Jauh (PJJ) memerlukan waktu yang lebih lama untuk memahami materi, tugas serta informasi lainnya dibandingkan pembelajaran secara tatap muka. Hal tersebut juga dipengaruhi oleh ketidakseimbangan antara lingkungan yang kurang kondusif, motivasi serta informasi yang terus bertambah. Penambahan informasi mengakibatkan kendala belajar pada siswa, karena information overload dapat

Tabel 2. Hasil pengolahan uji normalitas data

One-Sample Kolmogorov-Smirnov Test

Unstandardized Residual

\begin{tabular}{|llr|}
\hline Normal Parameters ${ }^{\mathrm{a}, \mathrm{b}}$ & & \\
& & \\
& Mean &, 0000000 \\
\cline { 2 - 3 } & Std. Deviation & 3,89569244 \\
& Absolute &, 088 \\
\cline { 2 - 3 } & Positive &, 053 \\
\cline { 2 - 3 } & Negative &,- 088 \\
\hline Test Statistic & &, 088 \\
\hline Asymp. Sig. (2-tailed) & &, $084^{c}$ \\
\hline
\end{tabular}

a. Test distribution is Normal.

b. Calculated from data.

c. Lilliefors Significance Correction.

sebagai bantuan dalam memberikan pemahaman terhadap peran, lingkungan afektif, dan pengaruhnya. mengakibatkan stres (Delpechitre et al., 2019; Zhang et al., 2020: 4) dan meningkatkan kelelahan emosional pada setiap penggunanya 
(Marie et al., 2012a; 2012b; Zhang et al., 2020: 4).

Beberapa upaya dilakukan oleh siswa seperti menjalin komunikasi bersama guru dan teman, melakukan pencarian informasi termasuk pengelolaan informasi dalam mengatasi kendala belajar yang sedang dihadapi. Berikut merupakan hasil perhitungan uji normalitas, uji linearitas, dan uji regresi linier sederhana pada variabel manajemen informasi pribadi dan kendala belajar siswa saat pandemi Covid-19:

Tabel 3. Hasil pengolahan uji linearitas data

ANOVA Table

\begin{tabular}{|c|c|c|c|c|c|c|c|}
\hline & & & $\begin{array}{l}\text { Sum of } \\
\text { Squares }\end{array}$ & df & $\begin{array}{l}\text { Mean } \\
\text { Square }\end{array}$ & $\mathrm{F}$ & Sig. \\
\hline \multirow{5}{*}{$\begin{array}{c}\text { Kendala } \\
\text { Belajar * } \\
\text { PIM }\end{array}$} & \multirow{3}{*}{$\begin{array}{l}\text { Between } \\
\text { Groups }\end{array}$} & (Combined) & 1252,369 & 30 & 41,746 & 3,213 & 000 \\
\hline & & Linearity & 670,475 & 1 & 670,475 & 51,600 & ,000 \\
\hline & & $\begin{array}{c}\text { Deviation from } \\
\text { Linearity }\end{array}$ & 581,894 & 29 & 20,065 & 1,544 & ,080 \\
\hline & \multicolumn{2}{|c|}{ Within Groups } & 753,631 & 58 & 12,994 & & \\
\hline & \multicolumn{2}{|r|}{ Total } & 2006,000 & 88 & & & \\
\hline
\end{tabular}

Tabel 4. Hasil pengolahan uji regresi linear sederhana

ANOVA $^{a}$

\begin{tabular}{|l|l|r|r|r|r|r|}
\hline \multicolumn{2}{|l|}{ Model } & Sum of Squares & df & Mean Square & F & Sig. \\
\hline \multirow{2}{*}{1} & Regression & 670,475 & 1 & 670,475 & 43,677 &, $000^{\mathrm{b}}$ \\
\cline { 2 - 7 } & Residual & 1335,525 & 87 & 15,351 & & \\
\cline { 2 - 7 } & 2006,000 & 88 & & & \\
\hline
\end{tabular}

a. Dependent Variable: Kendala Belajar

b. Predictors: (Constant), PIM

Tabel 5. Hasil Pengolahan Model Regresi Linear

Model Summary

\begin{tabular}{|l|r|r|r|rr|}
\hline Model & \multicolumn{1}{|c|}{$R$} & \multicolumn{2}{|c|}{ R Square } & Adjusted R Square & \multicolumn{2}{|c|}{$\begin{array}{c}\text { Etd. Error of the } \\
\text { Estimate }\end{array}$} \\
\hline 1 &, $578^{\mathrm{a}}$ &, 334 &, 327 & 3,918 \\
\hline
\end{tabular}

a. Predictors: (Constant), PIM

b. Dependent Variable: Kendala Belajar 
Manajemen informasi pribadi dapat dijadikan sebagai salah satu upaya dalam mengatasi kendala belajar siswa. Choo (1995; Auster \& Choo, 1995; Choo, 2002: 5) mengungkapkan bahwa tujuannya untuk membantu siswa dalam mengatasi berbagai permasalahan yang tengah dihadapi dengan menemukan informasi yang tepat, untuk orang yang tepat, di waktu yang tepat, jumlah dan media yang tepat. Berdasarkan tabel 2 hasil uji normalitas data penelitian ini terdistribusi normal karena nilai signifikansi lebih dari 0.05 yaitu 0.088. Lalu, hasil uji linearitas data yang menunjukan nilai signifikansi deviation from linearity sebesar 0.080 mengungkapkan bahwa terdapat hubungan antara variabel bebas dan variabel terikat. Kemudian hasil penelitian memberikan fakta dan data bahwa manajemen informasi pribadi memiliki pengaruh terhadap kendala belajar siswa. Pernyataan tersebut terbukti pada nilai $\mathrm{F}$ hitung yang menunjukan angka 43,677 dengan signifikansi sebesar,000. Besaran pengaruh dapat terlihat pada tabel 5, dengan $R$ square (koefisien determinasi) sebesar 0.334. Angka tersebut bermakna bahwa besaran pengaruh manajemen informasi pribadi terhadap kendala belajar siswa sebesar $33,4 \%$.

\section{PENUTUP \\ KESIMPULAN}

Berdasarkan pemaparan hasil penelitian dan pembahasan terkait manajemen informasi pribadi oleh siswa SMAN 1 Cicalengka dalam mengatasi kendala belajar saat pandemi Covid19, dapat disimpulkan bahwa manajemen informasi pribadi dapat dijadikan sebagai upaya dalam mengatasi kendala belajar. Kemudian pernyataan tersebut diperkuat dengan hasil analisis data yang menyatakan bahwa terdapat hubungan antara manajemen informasi pribadi dengan kendala belajar. Selain itu, manajemen informasi pribadi memiliki pengaruh positif yang rendah terhadap kendala belajar siswa SMAN 1 Cicalengka.

Aktivitas manajemen informasi pribadi siswa SMAN 1 Cicalengka seluruhnya tergolong baik, akan tetapi masih terdapat beberapa aktivitas yang perlu diperhatikan dan ditingkatkan lagi pada setiap rincian aktivitasnya.
Khususnya pada aktivitas penyimpanan, pengorganisasian, dan pemeliharaan informasi yang menjadi penunjang kesuksesan proses temu balik informasi yang sesuai dengan kebutuhan siswa dalam mengatasi kendala belajar yang sedang dihadapi.

\section{SARAN}

Berdasarkan hasil penelitian tersebut kepala perpustakaan/pustakawan/tenaga perpustakaan SMAN 1 Cicalengka diharapkan dapat memenuhi kebutuhan informasi terbaru bagi seluruh komponen sekolah khususnya siswa-siswi. Kemudian diharapkan guru dan siswa dapat meningkatkan motivasi dengan memanfaatkan media yang mendukung. Lalu, siswa-siswi SMAN 1 Cicalengka diharapkan dapat meningkatkan kembali setiap tahapan pada aktivitas manajemen informasi pribadi ini, sehingga memberikan bantuan untuk menemukan informasi yang tepat dan sesuai dalam menetapkan suatu keputusan yang akurat di masa depan.

\section{DAFTAR PUSTAKA}

Al Nasar, M. R., Mohd, M., \& Ali, N. M. (2011). Personal information management systems and interfaces: An overview. 2011 International Conference on Semantic Technology and Information Retrieval, STAIR 2011, August 2016, 197-202. https://doi.org/10.1109/STAIR.2011.5995 788

Choo, C. W. (1995). Information Management for the Intelligent Organization: Roles and Implications for the Information Professions. 1995 Digital Libraries Conference, 81-99. https://tise2015.kku.ac.th/drupal/sites/de fault/files/Choo - IM for the Intelligent Organization - 1995.pdf

Darmawan, D. (2012). Pendidikan Teknologi Informasi dan Komunikasi (A. Kamsyach (ed.)). PT. Remaja Rosdakarya.

Detlor, B. (2010). Information management. International Journal of Information Management, 30(2), 103-108. https://doi.org/10.1016/j.ijinfomgt.2009.1 


\subsection{1}

Dutta, S., \& Smita, M. K. (2020). The Impact of COVID-19 Pandemic on Tertiary Education in Bangladesh: Students' Perspectives. Open Journal of Social Sciences, 08(09), 5368.

https://doi.org/10.4236/jss.2020.89004

Handayani, R. T., Arradini, D., Darmayanti, A. T., Widiyanto, A., \& Atmojo, J. T. (2020). Pandemi covid-19, respon imun tubuh, dan herd immunity. 10(3), 373-380.

Hardof-Jaffe, S., Hershkovitz, A., Abu-Kishk, H., Bergman, O., \& Nachmias, R. (2009). How do students organize personal information spaces? EDM'09 - Educational Data Mining 2009: 2nd International Conference on Educational Data Mining, 250-258.

Hwang, Y., Kettinger, W. J., \& Yi, M. Y. (2015). Personal information management effectiveness of knowledge workers: Conceptual development and empirical validation. European Journal of Information Systems, 24(6), 588-606. https://doi.org/10.1057/ejis.2014.24

livari, N., Sharma, S., \& Ventä-Olkkonen, L. (2020). Digital transformation of everyday life - How COVID-19 pandemic transformed the basic education of the young generation and why information management research should care? International Journal of Information Management, 55(June), 102183. https://doi.org/10.1016/j.ijinfomgt.2020.1 02183

Indratmo, \& Vassileva, J. (2008). A review of organizational structures of personal information management. Journal of Digital Information, 9(26).

Jones, W. (2007). Personal information management. Annual Review of Information Science and Technology, 41, 453-504. https://doi.org/10.1002/aris.2007.144041 0117

Jones, W., \& Teevan, J. (2008). Personal
Information Management.

Karim, N. S. A., \& Hussein, R. (2008). Managers' perception of information management and the role of information and knowledge managers: The Malaysian perspectives. International Journal of Information Management, 28(2), 114-127. https://doi.org/10.1016/j.ijinfomgt.2007.0 8.003

Lestari, A. (2016). Kiat-Kiat Cerdas Cendekiawan Muda Islam. PT. Elex Media Komputindo. https://books.google.co.id/books?id=ZixID wAAQBAJ\&pg $=P A 42 \& d q=$ kendala + belajar \&hl=en\&sa=X\&ved=2ahUKEwil5rjKg6jvAh VLfisKHabhCvcQ6AEwBHoECAYQAg\#v=on epage $\& q=k e n d a l a$ belajar $\& f=f a l s e$

Lush, A. (2014). Fundamental personal information management activities Organisation, finding and keeping: a literature review. In The Australian Library Journal (Vol. 63, Issue 1, pp. 45-51). Taylor $\&$ Francis. https://doi.org/10.1080/00049670.2013.8 75452

Majid, S., San, M. M., Tun, S. T. N., \& Zar, T. (2010). Using internet services for personal information management. Communications in Computer and Information Science, 96 CCIS, 110-119. https://doi.org/10.1007/978-3-64216032-5_10

Nations, U., \& Programme, D. (2020). COVID-19 UNDP's Integrated Response. 1-8.

Neuwirth, L. S., Jović, S., \& Mukherji, B. R. (2020). Reimagining higher education during and post-COVID-19: Challenges and opportunities. Journal of Adult and Continuing Education, 2059. https://doi.org/10.1177/14779714209477 38

Rinawati, D., \& Darisman, E. K. (2020). Survei tingkat kejenuhan siswa SMK belajar di rumah pada mata pelajaran produk kreatif dan kewirausahaan selama masa pandemi covid-19. Journal of Science and Education, 1(1), 32-40. 
Riyanto, S., \& Hatmawan, A. A. (2020). Metode Riset Penelitian Kuantitatif Penelitian di Bidang Manajemen, Teknik, Pendidikan dan Eksperimen. Penerbit Deepublish.

Robinson, S., \& Johnson, F. (2012). The process and affective environment of students' personal information management. Enhancing Learning in the Social Sciences, 4(2), 1-13. https://doi.org/10.11120/elss.2012.04020 005

Shafira, A. N. (2020). Implementasi Personal Information Management (Pim) Mahasiswa Tingkat Akhir Pada Program Studi Perpustakaan Dan Sains Informasi. Universitas Pendidikan Indonesia.

Siyoto, S., \& Sodik, M. A. (2015). Dasar Metodologi Penelitian. Literasi Media Publishing.

Suhardini, D. (2011). Peranan Manajemen Perpustakaan Sekolah Dalam Mendukung Tujuan Sekolah. Edulib, 1(1), 11-26. https://doi.org/10.17509/edulib.v1i1.1140

Thomson, A. J. (n.d.). Information management and data registration. https://www.google.com/url?sa=t\&rct=j\& $\mathrm{q}=\&$ esrc $=\mathrm{s} \&$ source $=w e b \& c d=\& c a d=r j a \& u a$ $\mathrm{ct}=8 \&$ ved $=2$ ahUKEwjOllmyjJvvAhUxiOYKH YOCBTE4HhAWMAh6BAgJEAM\&url=http\% 3A\%2F\%2Fwww.fao.org\%2Fforestry\%2F44 $863-$

0a0a898a57b103e2c2aee9fe63fe4a470.pd f\&usg=AOvVaw1GoVYVIKFjCOy1dMEXNVy $f$

Wahyuni, N. (2019). Pelaksanaan Manajemen Informasi Pribadi Pada Aplikasi Memo Smartphone (Studi Kasus Mahasiswa Kehutana Angkatan 2015) (Vol. 11, Issue 1) [Universitas Sumatera Utara]. http://scioteca.caf.com/bitstream/handle /123456789/1091/RED2017-Eng-

8ene.pdf?sequence $=12$ \&isAllowed $=\mathrm{y} \% 0 \mathrm{Ah}$ ttp://dx.doi.org/10.1016/j.regsciurbeco.20 08.06.005\%0Ahttps://www.researchgate. net/publication/305320484_SISTEM_PEM BETUNGAN_TERPUSAT_STRATEGI_MELES TARI
Whittaker, S. (2011). Personal information management: From information consumption to curation. In Annual Review of Information Science and Technology (Vol. 45, pp. 1-62). https://doi.org/10.1002/aris.2011.144045 0108

Wiresti, R. D. (2020). Analisis Dampak Work From Home pada Anak Usia Dini di Masa Pandemi Covid-19. Jurnal Obsesi : Jurnal Pendidikan Anak Usia Dini, 5(1), 641. https://doi.org/10.31004/obsesi.v5i1.563

Zhang, X., Ding, X., \& Ma, L. (2020). The influences of information overload and social overload on intention to switch in social media. Behaviour and Information Technology.

https://doi.org/10.1080/0144929X.2020.1 800820

Zhang, Z. (2016). Effect of mobile personal information management on university students' perceived learning effectiveness [The University of Hong Kong]. In The University of Hong Kong (Pokfulam, Hong Kong). https://doi.org/http://dx.doi.org/10.5353/ th_b5812723 